\title{
SHARE THE VISION ON BUDDHIST PHILOSOPHY OF EDUCATION
}

\author{
Ven. Mediyawe Piyarathana Thero \\ Bhiksu University of Sri Lanka, Anuradhapura, Sri Lanka \\ Email: revpiyarathana@busl.ac.lk
}

\begin{abstract}
The objective of this research paper is to share the vision on Buddhist Philosophy of Education. At the time of the Buddha, the education system was considered mainly as a religious one, although the education concept was a pre-Buddhist one. The main objective of the Buddha was not to introduce an education system to the world; however, The Buddha was really a religious teacher who introduced a practical and living philosophy to the entire human community. Since Buddha was a person who understood reality fully as an Enlightened One, he introduced a living philosophy targeting the entire human beings through various teaching methods. It is possible to explore the Buddhist Philosophy of Education by exploring the teachings of the Buddha.
\end{abstract}

Educability is accepted in Buddhism at a great level as a principle. The Buddhism emphasizes in the Eight-Fold Path that volition and try, enthusiasm and courage are necessary factors. The way a person should act to end demerit and for the improvement of merit is given under Four Great Efforts. Educability is not a possibility to receive from a religion, not accepting the potentiality of person. The Buddhism has emphasised through many discourses that a person has to achieve objectives without resorting to any external elements. From the teachings of the Buddha, educability and potential energy of a person have been included as essential components in Buddhist Philosophy on Education.

According to Buddhism, personality can be presented as the only strength that a person possesses to act with volition and self-confidence. Buddhism first teaches person to create good conduct by disciplining the organs like body, speech etc. then advises for his spiritual development. The personality of the one who has become an Arahant is more than all those persons. The whole purpose of the Buddhist education is to develop the personality of person. When it is compared with the objectives of modern education, Buddhist education objective seems to be a wide and deep one. If the features of personality are seen with students, it can be considered great. The society with them is peaceful. Buddhism has presented the facts like liquor, gambling and misconduct that cause personality into decay and destroy. It is clear that all the necessary advice for a student to develop personality is given by Buddhism.

Buddhist education is a way to end all the mental ills like lust, faults and ignorance through the entire physical and mental discipline and can be a way of gaining spiritual purity. Discipline, an important education objective, is the controlling body and speech. The knowledge that a person gains on crafts without any discipline is not for the good of society, but the Buddhist view is that it should be with ethics. The intelligence of the person, who is without virtue and discipline, is fruitless. It is clear from one of the main activities of an education process is training members to live honouring the other members of the society. The object of Buddhist education is to teach person keeping him as the centre and subordinates in various social status by keeping close relationship with them from childhood and how to live a fruitful life

One important thing that Buddhism expects is to create a person with high self-confidence. According to Buddhism, the greatest self-confident person is not to worry even facing with Eight Worldly Conditions. Teaching how to face eight worldly conditions is trained with the objectives of Buddhist education. 
Discourse on Loving-kindness states which presents person to live a wealthy life, education, family life condition, living environment, the position of his parents and by thinking about them to live with what is available. Confirming a lifestyle of good conduct is the objective of Buddhist education. Another objective of Buddhist education is to train person to look at oneself and others with love and respect. Without being selfish and leading to act selflessly is done with this objective. The main code of ethics of Buddhism, Pancasīla (Five Precepts), is the principle of protecting human right. The objective of Buddhist education is to create the well-being or benefit of person and society. It is very clear now that five precepts are necessary to create world peace and to end the worldwide spread environment of unrest or intolerance and for the human right protection

Where Buddhist education aims and objectives are concerned, there are few important facts in the Discourse on Blessing 'Vast learning, perfect handicraft, a high trained discipline, and pleasant speech. This is the Highest Blessing. Vast learning means gaining a vast knowledge. In a religious sense, it is learning about nine-fold Dispensation and the ability to describe them in various ways. The objective of Buddhist education is not only to give this energy, but it is necessary to put those theories into practice. Buddhist education philosophy is with the objective of creating complete lifestyles of the masses.

It is very clear that the initial and final objective of Buddhist education is purifying mind. The Buddhist education system has been formed in a way that it shows life objectives and education objectives. By cultivating all the things of the character of the student who gets education, the objective of education is to create a good person to the society. So, there should be a service to the society and it is the main concept of the Buddhist education. If the society is formed with the above mentioned education objectives, there won't be any social problem, complexity or any corruption. In this manner, for the benefit of social expertise, it is possible to understand how people get help and support from Buddhist doctrine. The researcher expects to share the vision on Buddhist Philosophy of Education for the benefit of society through this research.

Keywords: Buddhist Philosophy of Education, Educability, Education Philosophy, Buddhist Education \& Discipline.

\section{Objective}

The objective of this research paper is to find out whether Buddhism presents any Philosophy of Education in the Buddhist doctrine (Ti-pitaka, Three Baskets). After investigating the teachings of the Buddha, it is intended to share the vision on Buddhist Philosophy of Education.

\section{Overview}

Philosophy of Education is the collection of ideas regarding the nature of education that should be given to people and how its features should be composed. In this process, the education factors, such as the role of education, philosophy, ethics, processing (learning), goals, methods, techniques, relationship between teachers and students, syllabus etc. are taken into consideration. Since most of these factors can be found in the Buddhist doctrine, it is possible to reveal the Buddhist Philosophy of Education through research.

\section{Methodology}

With the purpose of finding the Buddhist Philosophy of Education, Buddhist canonical texts were mainly used in this research. 


\section{Research Problem}

What is the Philosophy of Education presented in Buddhism?

\section{Discussion of Data \& Analysis Buddhist Education: Historical Background}

When the philosophy of Buddhist education is concerned, it is necessary to investigate the history in brief. The education concept of the East is relatively a pre-Buddhist one. The beginning of the Indian Aryan people's education goes back to the time before the advent of Aryan people to India. The education of the indigenous people who lived in the era of IndoAryan migration goes to the pre-historic time of Mohendojaro-Harappa Indo-Valley civilization. At the time of the Buddha, the education system that spread in India was a system accepted by Brahmin clergy community. This was mainly considered as a religious education.

For the understanding of the nature of the scholars who got the maximum benefit of the Brahmanic education, it is necessary to look at the following expression of Ambatta Suttain (Nikiya \& Davids, 1995, p. 88). Now, at that time Pokkharas $\triangle i$ had a pupil, the youth $A m b a_{\supseteq} \supseteq h a$, who was a student of the Vedas, who knew the Mantras, perfected in the Three Vedas, a skilled expounder of the rules and rituals, the lore of sounds and meanings and fifthly, oral tradition, complete in philosophy and in the marks of a Great Man, admitted and accepted by his master in the Three Vedas with the words; what I know, you know, what you know, I know(Nikiya \& Davids, 1995, p. 88).

Those who were dedicated for the study of Veda were Brahmanic princes from Brahmanic lineage or clan. Royal princes, as well as princes from noble caste learnt arts of weapon and ruling related with all the arts and sciences (crafts). Apart from them, there had been people who used various arts as their living means or the jobs and it can be thought that those arts had been included in education syllabus. There are many arts or sciences mentioned in $S \sqsubset m a \square$ apala Sutta and those sciences had been used for living by the Brahmins and some other clergy community. Among them, the main areas are Anga Sastra (feature science) Nimitta Sastra (sign science), Swapna Sastra (dream science) Laksana Sastra (beauty science), Wastu Vidya (architecture) and Santi Kamma (ceremonial dance or ritual)(Nikiya \& Davids, 1995, pp. 47-86).

It can be noted that with the basis of the Brahmanic education system, all the other academic subjects related to social institutions and the wisdom spread. So, it is clear that from the Brahmanic education, the society inherited such arts and sciences as ethics, logic, mathematics, philosophy, astrology etc. Therefore, it is obvious that the Brahmanic education system helped timely to fulfil social and personal needs. But, since the Brahmins clergy community, who spread the education system in society, made the rules and regulations to deprive one section of the society from inheriting social and human privileges. The fortune of gaining the education was only with the children from the noble families. The women were also deprived of the education from their religious texts. Women were thought to be illiterate and unable to bare the social responsibilities.

\subsection{Buddhist Education System: Philosophical Background}

The Buddha was, in fact, a religious teacher who introduced a practical philosophy to the world and his main objective was not to introduce an education system to the world. He realised that, at the time of his origin to the world, the philosophy about the world and person which prevailed in India was a corrupt one full of defilements. He has said it in the following manner. "In the olden days in Magadaby the religious teachers with defilementsoriginated a doctrine with defilement (Nettananda, 1973, p. 168).” 


\section{Asia Pacific Journal of Advanced Business and Social Studies \\ ISBN (eBook): 9780994365675 | ISSN : 2205-6033 \\ Year: 2017, Volume: 3, Issue: 2}

Since the Buddha is a fully Enlightened One (Samma Sambuddha), he had a firm selfconfidence due to that propound understanding of the reality, he had considered that it was a foremost duty of him to introduce a practical and a living philosophy to the entire human

community (Nettananda, 1973, p. 171).The living philosophy introduced by him had directed all the human beings irrespective of the location, time etc. As this philosophy, which suits all the psychological features that behaves in every person, is with a common objective, it is considered that the doctrine is to continue for the whole life time of the each person.

In this manner, as the Buddha introduced a living philosophy, targeting the entire human beings, it is possible to explore the way that the education system works in the philosophy. By the ways in which He introduced His philosophy through various teaching methods, the Buddha himself has introduced the education system that should accompany when teaching the living philosophy. The other thing is that the Buddha presented was His teachings in the medium of education. It is possible to examine the nature of Buddhist Philosophy of Education by observing the techniques used by the Buddha in His teaching medium.

When all the definitions on the education introduced by the modern educationists are considered, the main purpose of education seems that it should be an activity that organizes the development of a person's life in a way that it supports the progress of the country, a social well-being and a good living condition. This must be carried out with some philosophical background. The education system, without a definite objective and the strategies to achieve it, will not help for the success of the lives of persons, but it will confuse the well-being of persons. Giving the knowledge to a person of a subject or several subjects is not solely accepted as education. According to modern education policies, proper education has the responsibility to lead the community with a common policy and objective.

Buddhism accepts the entire human society as a single unit. Buddhism does not distinguish all the differences like locality, time, race, caste etc. in the activities related to the benefit of humankind. From those differences, neglecting certain races is not suitable to the philosophical view presented by the Buddha. Buddhism has identified a common fundamental or principle affecting the entire beings. It is that all beings like happiness and dislike unhappiness(Dhammananda \& Pili, 1982, p. 131). It is willingness to happiness and the desire for living(Dhammananda \& Pili, 1982, p. 130).On the basis of this fundamental, Buddhism expects well-being of all the beings(Nipita \& Andersen, 1997, p. 25). Under this fundamental, although all the beings should be taken as a single unit, in the concept of personal benefit due to volition (swacchandat $\square$ ) and enthusiasm, human beings are considered as a single unit because Buddhism has accepted that only human beings can act with volition and enthusiasm.

Since education operates for the benefit of human beings and Buddhist way of education that is completely connected with the human beings is none other than an education system. Therefore, Buddhist Philosophy of Education means the philosophical view of Buddhism. It seems that it is a timely decision to share the Buddhist vision of Buddhist Philosophy of Education. On the other hand, whatever activities that should be followed by human beings and if it operates without Buddhist philosophical view, Buddhism acknowledges that it is not for the benefit of the mankind but for the detriment of man. So, it generally proves that Buddhist Philosophy of Education must be based on Buddhist philosophical point of view. It is clear now that Buddhist Philosophy of Education and Buddhist philosophical point of view are not two but one.

It is not possible to have the right view ( $s a \propto m \square d i \supseteq \supseteq h i$ ) in the education which is not concerning the reality of the persons and the world. Whenever the activity is taken without Saœm Ditthi or the Right View, the expected results cannot be reached. According to 


\section{Asia Pacific Journal of Advanced Business and Social Studies \\ ISBN (eBook): 9780994365675 | ISSN : 2205-6033 \\ Year: 2017, Volume: 3, Issue: 2}

Buddhism, right view is to look at the reality of the person and the world. This reality has been described in Buddhism in Four Noble Truth (Catur rrya Sacca). It is possible to present this reality of Buddhism in the following manner in brief.

The world, including man, is an origin with the cause and effect. It is known as Paticcasamupp $\square d a$ in Buddhism. The cause and effect doctrine (paticcasamup $\square d a$ ) is the nature of all the things in the world. Man is not an exception of it. Everyexisting thing (paticcasamuppa=na) is not eternal ( $\triangle$ swata)(Nikoya \& Feer, 1989, p. 17). And also, it is not an extinction or annihilationism (Ucceda). There are three signs presented by the existing things (sank $\square \mathrm{ra}$ ). They are impermanence (anicca), unsatisfactoriness (dukkha) and selflessness (an tma)(Dhammananda \& Pili, 1982, pp. 277-279). Sometimes, this is represented from the features as origin, changing and destruction(Abhayawansa, 2004, p. 152). People accept the permanency of the things in the world and complete non-existence due to their unawareness of the reality well. If a person sees the world and the origin of the world with a good wisdom or insight, he can eradicate the idea of permanency of things and negation(Vilsin \& Hewawitarana, 1929, p. 17). For the one who sees the destruction (nirodha) of the world or person with the good wisdom, the idea of the availability of things (astitwa) disappears(Vilsin \& Hewawitarana, 1929, p. 17).

Since all the things of the world origin with a cause and effect (pratitya samuppanna), those are not the creations of any Creator (xshwar, Siva,Master). Therefore, for the existence of man and his activities, there is no effect of Creator. Another feature of cause-effect (paticcasamuppa $=$ nat $\square$ ) is that something continues till the cause exists. And it continues as connected series of things. With the end of the cause or with the stopping of the cause, the end of a thing or person occurs (Vilsin \& Hewawitarana, 1929, p. 70). This theory operates even within the person. When the person is considered, the reasons for the birth of a person are the mental defilements (kilesa) like desire or lust (trusna), ignorance (avidya) etc. If the person doesn't destroy the cause or the reasons like defilements, he undergoes a life in the world eternally (Sans $\square$ ric life). Reasons for the life in the world and continuation in the world are the series of actions ( $\mathrm{Ka} \propto \mathrm{ma}$ ) derived from physical, verbal and mental media with the desire (trusna). This action is twofold. One of them is the merit (kusala ka $\propto m a)$, that is done physically, verbally and mentally with a pleasant or pure mind and that gives good results(Dhammananda \& Pili, 1982, p. 2). The actions done with a wicked mind are the demerits (akusala ka $\propto \mathrm{ma}$ ) and they give bad results(Dhammananda \& Pili, 1982, p. 1). Since the existence of the world is with the cause and effect (paticca samuppanna), its main feature is suffering. To be free from this suffering, it is necessary to end the desires (trusna). Ending of desire means none other than the ending of suffering. It is essential to end the suffering or the unsatisfactory nature of things through the way to the cessation of suffering (dukkha nir $\downarrow$ dha $g \_$mini patipad $\downarrow$ ). This cessation of suffering itself is extreme happiness which is known as Parama Suka.

The above explained are some facts presented by the Buddhist philosophical view. At first sight, this seems to be a person-based philosophy. But, the person who makes the ownership of the philosophy acts in the social setting or unity. Therefore, Buddhist philosophical view, centred the entire society, operates in a socially applicable way in the following manner.

The person, who has the understanding of the reality that all the cause-effect originated things have the common features such as impermanence (anicca), unhappiness (dukkha), and selflessness (anatta), differs in attitude and behaviour from the person without the knowledge of them. He does not have the attitude of looking at selfless, changing and unsatisfactory things with lust or anger. When the desire (trusna) is not there, the resulted giving up (nekkhamma saøkappa) and due to the unavailability of anger, the resulted love (avyap $\triangle$ da sankappa, the result of it is the arising of the attitude of friendliness towards 


\section{Asia Pacific Journal of Advanced Business and Social Studies \\ ISBN (eBook): 9780994365675 | ISSN : 2205-6033 \\ Year: 2017, Volume: 3, Issue: 2}

everything (avihins $\square$ sa $k a p p a$ ). If someone acts without desire and anger and acts with a friendly attitude, not only his physical and verbal activities but also the living way become righteous(Abhayawansa, 2004).

People are used to considering the society as self and others because they haven't understood the reality of the world. When a person has the feeling that everything origin with cause and effect, he does not have the feeling of 'selfness' (na ca $\downarrow \downarrow$ aha casmi). When there is not the feeling of ' $I$ ', there is no feeling 'my or selfness' (na etan mama). As a result of the feeling 'I' and 'my' will arise the feeling 'others' and 'others' '. By considering that oneself or ' $\mathrm{I}$ ' is higher, the person tries to do anything for the benefit of him and thinking others are lower, the person tries to do anything for the disadvantage of others, this is because he does not have the understanding of the reality. The attitude of self-centered and thinking the benefit of oneself reasons for all the destructive things in the world. Without a deference of self or others and the thing of self and others, looking at the world with the attitude of sameness (sam $\square$ nattat $\square$ ) arises only when a person has the Right View (samyag drusti). If the objective of education is the benefit of person and society, there is no suspicion that Philosophy of Education should be the philosophy of reality represented by Buddhism.

\subsection{Buddhist Education: The Possibility of Educating (Educability)}

It is necessary to examine whether persons have the educability or the ability to get the knowledge for using education as a medium of giving benefit to person and society through giving the knowledge. According to Buddhist philosophy, the educability is naturally with person and the Buddhist view of educability is composed with Buddhist Philosophy of Education. The philosophy that person is cause-effect originated and it's becoming the Buddhist philosophy is explained above. Under the cause-effect principle, all the determinisms that have been presented about the nature of person are refused by Buddhism because determinism hands over the responsibility of person's activities to other external forces or powers. When person does not have the responsibility of his actions, he does not have the chance to make decisions and act accordingly. In that manner, the educability of person is refused under determinism. Buddhism refused all kinds of determinisms because from those, the educability of person or the ability of person getting knowledge and also the ethical responsibility of person is not with person but upon the external element.

At the time of the origin of Buddhism in India, from among the determinisms (niyativ $\square$ da), Issaranimm $\square$ nav $\square$ da (creation by an almighty), Pubb@katah@tuv $\square$ da (the result of the previous actions) and Niyatisangativ $\square$ da (origin of things due to determinism) were main. By Issaranimm $\square$ nav $\square$ da, it is said that man and the universe has been created by a Creator (god). When such a view exists, there is no possibility for man to act mindfully and responsibly or in other words, man's actions are vetoed. If all the things happen according to God's will, human activities mean that his activities are not the actions done willingly and responsibly, but the actions happened according to the god's wish. Accordingly, there is no possibility of prevalence the educability of man. Educability is meant that a person can act willingly, make decisions, select the best things and act accordingly thinking the benefit of it. The most compulsory things of education are the facts of getting the knowledge of things, making decisions based on it and making use of those decisions for the benefit of self and society. The primary conditions for this are volition (swaccandat $\square$ ) and responsibility. The reason for unaccepting creation of a god in Buddhism has been given in the following way by Prof. W.S. Karunaratna.

"Since the Creator ( $\times$ svar) has created us in his unthinkable ways, the necessity of our endeavour in virtuous life will be no more. Not only have our endeavours in progress in various ways becomes useless, but also it turns into dangerous situation since it is an effect to the plans of the Creator and a disgrace to the greatness of the almighty. And also, through 


\section{Asia Pacific Journal of Advanced Business and Social Studies \\ ISBN (eBook): 9780994365675 | ISSN : 2205-6033 \\ Year: 2017, Volume: 3, Issue: 2}

the handing over all the things to the god, the responsibility of virtue becomes an unnecessary thing. It is because God is the course of cosmic responsibility. When the concept of Creator ( $\times$ svarnimmanav $\square$ da) is considered, Buddha has a great significance due to virtues. So, if people praise God for the good and disgrace in bad, the result of it will be the anarchy or

uncontrolling of virtue. No one is responsible for the thought and all activities done by a person and everybody. Therefore, the Buddha has refused the concept of Creator ( $\times$ svarnimm $\square$ nav $\square$ da)(Karunaratna, 2000, p. 81)”.

Determinism (niyativ $\square d a$ ) by name $P u b b \subset k a t a h e t u v \_d$ a (the resulting of previous actions) denies volition (swaccandat $\square$ ). That principle has been given in Devadaha Sutta(Nipita \& Andersen, 1997, p. 219).

All the experiences or enjoyments that a person undergoes like Sukha (happiness), Dukkha (unhappiness) and Adukkhamasukha (mixture of happiness and unhappiness) are due to previous actions (kamma). According to this PubbekataHetuv $\square$ da of the Jaina philosophy, a person's present is the result of the actions done in previous births. Since all the responsibilities have been assigned to the earlier actions or Kamma, according to this view, it is not possible to make a person's present according to his necessities. In other words, volition and enthusiasm of a person become useless. Buddha neglects this view because it gives up the virtues above mentioned and necessary for the benefit of a person. In the above mentioned discourse or Sutta, Buddha gives reasons for the neglecting this view in the following manner. "Oh! Monks!, for the one who accepts previously done actions (pubbekatahetuv $\sqsubset d a$ ) does not have willingness (chanda) or courage(Nipita \& Andersen, 1997, p. 219).”

At the time of the Buddha in India, another religious teacher was Makkhalig $\downarrow_{s} \_l a$. He has presented the determinism called Niyati Sangativ $\sqsubset$ da. It can be noted that more than the above described two determinisms; it thoroughly denies the volition of a person and ability of a person. This determinism of Makkhalig $\downarrow$ s $\triangle$ la has been given in $S \sqsubset m a \square \square$ aphala Sutta in the following manner. 'There is no cause or condition for the defilement of beings. They are defiled without cause or condition. There is no cause or condition for the purification of beings, they are purified without cause or condition. There is no self-power or other power, there is no power in humans, no strength or force, no vigour or exertion(Nipita \& Andersen, 1997, p. 53)'.

Without cause and effect, beings get destroyed. There are no reasons for the purification of beings. Beings purify without reasons and effects. There are no activities to be done for the benefit of oneself. There are no activities to be done for the benefit of others. There are no manly activities. Beings don't have energy, power or strength. Human beings and other beings have undergone change with nature and without self-energy, power or strength.

Such a view completely refuses a person's ability to get the knowledge. There is no possibility of the educability under such a view. Prof. $W$. $S$ Karunaratna says as follows by criticizing the view of Makkhal $\times g \downarrow s \_l a\left(n i y a t a v \_d a\right)$.

“ $G \downarrow d s$ \la's view amounts to an uncompromising determinism of a special kind. Everything in the past, present and future is so thoroughly and remorselessly determined in accordance with a special kind of God-less teleology that no man can help doing what he does and seeing what he sees happening around him. Hence, according to $G \downarrow_{s} \measuredangle l a$ there is no will, volition, exertion, intention, choice and manliness(Chandima, 2003, p. 167).”

Not only educability is accepted in Buddhism at a great level as a principle, but also it always gives advices to persons in a practical way to develop it. The Buddhism emphasizes in the 


\section{Asia Pacific Journal of Advanced Business and Social Studies \\ ISBN (eBook): 9780994365675 | ISSN : 2205-6033 \\ Year: 2017, Volume: 3, Issue: 2}

Eight Fold Path that volition and try, enthusiasm and courage are necessary factors. The way, that a person should act to end demerits or sin and for the improvement of merit or good deeds, is given under Four Great Efforts (catu samyag viriya) in Right Effort (samm $\square$ $v \sqrt{ } \triangle \mathrm{ma}$ ) and they are endeavour not create demerits that are not having, to end the demerits having, to create the merits not having and to magnify the merits having(Nipita \& Andersen, 1997, p. 15).

Educability is not a possibility to receive from a religion not accepting the potentiality of person. There is no other religious teacher than the Buddha who showed a person's potentiality. It is possible to awaken person about educability through education from others (paratoghosa) and from the wisdom with enlightened-thinking (yonisomanasik $r a$ ) (Manusmmriti \& Panday, 1969, p. 294). From these two, fruitfulness of education and the ability of person are accepted. Buddhism has emphasised through many discourses (suttas) that a person has to achieve objectives without resorting to any external elements. 'One truly is the protector of oneself; who else could the protector be?(Dhammananda \& Pili, 1982, p. 160)'.'You yourselves must strive; the Buddha only point out the way(Dhammananda \& Pili, 1982, p. 276).'From the teachings found in Buddhism like above, educability and potential energy of person have been included as essential components.

\subsection{Buddhist Education: Definitions on Education}

To find the definitions about education in Buddhism, it is important to analyse the definitions found in the $P \llbracket l i$ canon (ti-pitaka) when. The Sanskrit term for education is "Adhy $\sqsubset$ pana" and the P $\square$ li term "Ajjh pana" . In the Pali-English dictionary, the meaning of 'Ajjh $\angle$ pana' has been given as 'advising and educating'(Davids \& Stede, 1966, pp. 11-12). Sanskrit-English dictionary of Moniyar William gives the meaning for the education as 'advising and educating'. It says that the word is as ' $x$ ' verb toot with 'adhi' before (Williams, 1960, p. 22). According to this, it is very clear that both Sanskrit and Pâli terms have the same meaning. In the dictionaries Shabdakalpadruma, (Williams, 1960, p. 40) and $V\lceil$ casptya (Williams, 1960, p. 140), education has been explained as 'letting to learn from the teacher and giving the chance to read books'. From the word root of 'education', all the activities done by the students with the guidance of a teacher are included. It is necessary to examine the word 'education'. The meaning 'learning or listening from the teacher's words in the correct order and learn by heart' is here with the word 'education'(Williams, 1960, p. 40).

When education is concerned, the word 'Sikkh $\square$ ' found in Buddhist doctrine has to be taken into consideration. There are several meanings for this in Pali- Sinhalese Dictionary like 'studying, training and getting the discipline'. The words 'Sikkh $\square$, Sikkh $\sqsubset p a k a$ and Sikkh pana have been used with the meaning of education(Davids \& Stede, 1966, p. 708). For the word 'Sikkh $\square$ ' the meanings 'good conduct or virtue' and 'disciplinary conduct' are also included. By the term 'Sikkh $\_$pada', it is meant that there are the rules for the discipline. These Sikkh $\ulcorner s$ are necessary as a way of code of conduct for discipline. Sikkha meant 'the way for discipline'. These virtues are necessary till one attains deliverance (nibb $\_n a$ ) after ending all suffering and gaining the satisfaction. It is clear now that Sekhapa $\supseteq$ ipad $\square$ means this code of conduct. All these are included in education.

In the definition on education, the term 'Vinaya' (discipline) takes a special place. Vinaya means discipline, eradication of defilements (kilesa). Vinaya is physical and mental discipline. It has command about the virtue. So, it can be stated that the whole Buddhist education is included with the word Vinaya. The commentary by Vilsin \& Hewawitarana, (1929)has explained Vinaya in the following manner. 'Since it provides various, special, rules for physical, verbal and mental discipline, they are called Vinaya.' It is clear that the Buddha has intended from the term 'Vinaya' that it helps to end all the mental ills like lust, faults and 


\section{Asia Pacific Journal of Advanced Business and Social Studies \\ ISBN (eBook): 9780994365675 I ISSN : 2205-6033 \\ Year: 2017, Volume: 3, Issue: 2}

ignorance(Pili \& Hewawitarana, 1950, p. 3). According to this, it is obvious that Buddhist education is a way that, through the entire physical and mental discipline, it can be a way of gaining spiritual purity.

When the Buddha preached doctrine, he presented all the ascetic practices that were in India at that time, in a new approach and in a modest way with new definitions to them and also in an active manner. At the Agga $\square \square$ a Sutta of Digha Nikaya, for the meaning of 'Ajjhayaka', the described from education and related meanings, it is possible to give another meaning. The Brahmins took the meaning of 'the study of Veda and the one who studies Veda'. But, it seems that the Buddha has taken the meaning 'not doing Absorption (jhy $₫ a$ ), not learning

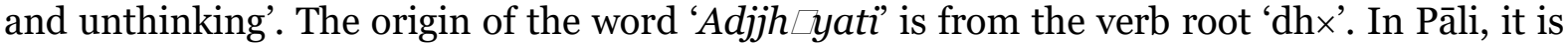
meant by the word 'Jhy yati' which means 'mind'.

It is useful to examine the way the word has been described in (Vilsin \& Hewawitarana, 1929). In it, the meaning of the word 'ajjh yaka' has given as 'they don't practise Absorption now'. Since they gave up Absorption at the beginning of the aeon, the word 'Ajjh $\square$ yaka' has been used for them. But now, they use it as a respectful term or word(Vilsin \& Hewawitarana, 1929, p. 172).

From the word 'Gn $\square$ na' in Buddhism, after referring it to the mind of person, it is meant to find something new and to get an understanding. The core of education is to get the student to creative thinking and self-understanding. If the person with an Absorptive mind engages in it with courage and enthusiasm, he is in a position to understand the reality (Dhammananda \& Pili, 1982, p. 23).

In this manner, it is possible for the mind-cultivating person to get a great understanding of a doctrine unheard and inexperienced before. Education means reaching this stage. From the term 'jhy $\square$ na' (Absorption) found in Buddhism give a very great meaning. But, it is not the end of Buddhist education. It ends after gaining the wisdom through listening (sutamaya $g n \sqsubset n a$ ) and finally thinking (ci=t $\square$ maya $g n \sqsubset n a$ ) and meditating.

\subsection{Buddhist Education: Aims and Objectives}

The collection of values decided by observing personal and social dimensions can be defined as objectives. The objective of education means the values that have to be understood for the betterment of person and as a whole public society (Hendri, 1977, p. 31). It is correct to accept in the above manner. Personal objectives, hopes and aims are different from person to person and society to society. But, it is not intended that there aren't common education objectives. Therefore, it is important to examine some of the views that have been expressed regarding this before analysing the Buddhist education objectives.

When the views, which have been expressed from the past up to now about the objectives of education, are concerned thoroughly, it is possible to categorize them into three types namely,

1. Considering personal benefit as more important

2. Considering social benefit as more important, and

3. Considering both personal and social benefit as equally important.

(Sri Lanka University, 1980, p. 23).

From these, the third objective is very important with regards to the Buddhist education objectives.

A person is born into the society as a member of the society. So, he is a person, citizen and, at the same time, a member of society. It is not possible for person to live alone. So, society means a vast organization created by people for the unity with different persons. That organization or unit must be created through the education process. That process consists of 


\section{Asia Pacific Journal of Advanced Business and Social Studies \\ ISBN (eBook): 9780994365675 | ISSN : 2205-6033 \\ Year: 2017, Volume: 3, Issue: 2}

education objectives. Education social scientists greatly emphasise that socialization process means the above objective. The main objective of Buddhist education is to form the individual and society.

The objective of education should be to awaken the attitudes, expectations and talents of person to the maximum level. The purpose of education is to give the necessary guidance for student to be a perfect member of society. From childhood, it is necessary to give the proper place that should be possessed by person. For everyone living in the society has some place

according to physical, mental and intellectual abilities. For a good citizenship, training as a good person means giving the necessary support to get his place in society. Mental development, controlling emotions and good physical condition are the proper features of a good citizen. It is necessary to develop these to the intended level by going with good aims and objectives.

There can be a question for someone as to how it is possible for one to decide the good or bad nature of the objectives. According to Buddhism, it is possible to solve this very easily. If an idea operates with defilement, anger and ignorance, it is a demeanour, bad and low one. If an idea operates with non-defilement, non-hatred and intelligence, it is a good one(Nipita \& Andersen, 1997, pp. 188-193).

When a person behaves in a society, it is possible to understand this with the attitudes and responses towards him from the others in society. One gets high social responses on the basis of the understanding due to the knowledge and experiences obtained dealing with the society. The Buddhist view is that high mental status cannot only be gained by intelligence ability training. For it, it is necessary to connect social virtues or good conduct. Therefore, it is possible to analyse that high mental features and high objectives are a combination or a mixture of intelligence and virtue. The best exemplary person represented by Buddhism is with devotion and wisdom. Others apart from these are cunning persons and pools(Vilsin \& Hewawitarana, 1929, p. 569). Both cunning persons and pools are not beneficial to the society. According to this, the objective of Buddhist education is to develop intelligence as well as virtues like kindness etc.

Mr. R. S. Peters says, "Creating persons with the awakening and critical mind is an objective of education(Peters, 1966, p. 31)." The nature of the mind with critical mind is not to fill mind with inactive knowledge or thoughts, but accepting things with an understanding with the help of knowledge from books, teachers and society. Others like to introduce these features as mental culture(Whitehead, 1929, p. 13). Mental culture or critical nature introduced by modern educationalists was been expressed by Buddha as the objectives of education. The Buddha has preached the objectives of education in detail to a group of Brahmin students in village named Kesaputta(Nipita \& Andersen, 1997, p. 189). Professor L.G. Hewage points out that the objective of Buddhist education is to understand things in their real nature (Hewage, 1970). This is not a strange thing for Buddhism that gives priority to reality.

\subsection{Buddhist Education: Development ofCharacter}

Before paying attention to the point that the Buddhism builds onto the development of character, it is important to what is meant by the development of character. It is no doubt that, most of the time, one's character is determined by looking at his physical activities. But, to say that he is a noble character not only his threefold activity i.e. physical, verbal and mental behaviour patterns but also his discipline with regard to society that he lives in, and culture should be soft. It is possible to say that the person possessing all these above characteristics is a good character with good behaviour. Sometimes, of the person with a good physical conduct, other activities can be ruined. It is not possible to expect a benefit 


\section{Asia Pacific Journal of Advanced Business and Social Studies \\ ISBN (eBook): 9780994365675 I ISSN : 2205-6033 \\ Year: 2017, Volume: 3, Issue: 2}

and blessing to the society. By cultivating all the things of the character of the student who gets education, the objective of education is to create a good person to the society. So, there should be a service to the society and it is the main concept of the Buddhist education.

Buddhism first teaches person to create good conduct by disciplining the organs like body, speech etc. then, advises for his spiritual development. 'Good is restraint in the body; good is restraint in speech; good is restraint in the thought; restraint everywhere is good (Dhammananda \& Pili, 1982, p. 361).'This preaching clearly states the above fact. Buddhism advises to give up all the misconducts committed bodily, speech and mind considering them

as demerits. Through the teachings like "atta sa $\propto m \square$ panhidhi”, getting a high place for the development of character and has explained that it helps for the worldly progress and beyond. Educationalists, who introduce the features of a person who possesses high moral conduct, point out that he should possess features like activeness, constant energy, belief, leadership, discipline and compassion. When analysing the above closely, it can be noted that the teaching found in discourse on loving-kindness (Metta Sutta) "sakk $\downarrow$ uj (ca s $(j$ (ca" is here. Sakk $\downarrow$ means activeness. Even for the other necessary guidance is provided by this discourse itself.

\subsection{Buddhist Education: the Development of Personality}

When the development of personality is taken as a Buddhist Philosophy of Education, it is better to examine what personality means. When personality is taken into consideration, many assume that it is the physical nature of a person that has grown well. But, it is not the right personality. According to Buddhism, personality is the extreme development of physical and mental power. The collection of all the behaviour patterns of a person that can be compared only to him is personality. Complex reactions like the way one looks at the world, his objectives and likes, the things he is interested and uninterested things, the ability to do something, inability, problem solving way, the way people think and their expectations in life etc. are included to the above behaviour pattern. Both behaviour patterns observable externally and the behaviour patterns that can be guessed are also implied personality(Nettananda, 1973, p. 166). It is clear from this that the complete person with all the characteristics is included into the concept of personality.

According to Buddhism, personality can be presented as the only strength that person possesses to act with volition and self-confidence. This fact can be confirmed when the ideas included in Buddhism are considered. The Buddha does not hand person over to an almighty. He considers personality as a great factor. According to the knowledge obtained through extreme practices (duskara ka $\propto \mathrm{ma}$ ), he preached that self-salvation or deliverance is with self not with any other person. Like in other religions, Buddhism does not hand over the personality to a god. Buddhism accepts is that personality is owned by person himself. Buddhism emphasizes that one's master none other than self.

'One truly is the protector of oneself; who else could the protector be?'(Dhammananda \& Pili, 1982, p. 160).

'One should live as light to oneself; one is the help for oneself; no one else.'

'Purity and impurity depends on one-self; no one can purify another.'(Dhammananda \& Pili, 1982, p. 165).

It is clear from this that Buddha has given personality a special place in his doctrine. Also, he has considered courage possessed with person as a great thing. Thought, effort, courage, rising, valour, departure, beginning and things for the beginning are some of the words that the Buddha has introduced the personality. From these, a person's own self is appreciated and at the same time, it emphasises that person has the freedom and responsibility to develop the personality willingly. It is possible to see some idea about developing personality 


\section{Asia Pacific Journal of Advanced Business and Social Studies \\ ISBN (eBook): 9780994365675 | ISSN : 2205-6033 \\ Year: 2017, Volume: 3, Issue: 2}

of Buddhist doctrine when considered the expectant results of Four Noble Truths (MagaPhala, ways and results of stream entry)(Hawanapola \& muladarma, 1974, p. 58). There is a more personality development of the one who attained Sakadh $\square$ g $\square i$ (once-returner to this world) than the person who Sov $\square n$ (first stage of Arahantship or stream-enterer) attained. More than these two, there is more personality development in the one who has attained An $\square$ gami (non-returner). The personality of the one who has become an Arahant is more than all those persons. The whole purpose of the Buddhist education is to develop the personality of person.

When it is compared with the objectives of modern education, the Buddhist education objective seems to be a wide and deep one. If at least some of these personality features are seen with some students, it can be considered great. The society with them is peaceful. In other words, it is possible to say the self-good as personality. It is not possible to hold leadership to the person without personality. He will be incapable to live as good person in society. From it, not only he, but also the associates will go into ruin.

Buddhism has presented facts that cause personality into decay and destroy. Liquor, gambling and misconduct are some of them(Nipita \& Andersen, 1997, p. 19). In this way, it is clear that all the necessary advice for a student to develop personality is given by Buddhism.

In common, training of a student for a good citizenship is also an objective of Buddhist education. Training for citizenship is giving efficiency for all the areas of person. The Buddha guided his followers not only for the benefit of life after death, but he also advised for the good of this life. Buddha's aim was to create a good society and make self-purity of all the members of society. And also the Buddha wanted to advise all to get self-liberation or Nibbh $\sqsubset n a$. This purpose is so clear according to many discourses (suttas).

The Buddha accepted that for the good or bad of person, the caste whether high or low does not matter but the society that person associates is the main cause for the benefit or deterioration. Therefore, he gave the necessary advice for a good society. 'Not to associate with the fools; to associate with the wise.' From this found in Mangala Sutta (discourse on blessing), it can be seen that the Buddha, at first, arranges the social environment of person(Nipita \& Andersen, 1997, p. 46). Doctrinal matters that are helpful worldly life like earning money, benevolent conduct or helpfulness etc. are there in Buddhism. Discourses like $S i=g a l o v \square d a$ and Vyagghapajja, helps for the benefit of this world or worldly life while the discourses like $M a=g a l a$ and Par $\triangle$ bhava guide for both worldly life and beyond.

The object of Buddhist education is to teach person keeping him as the centre and subordinates or various persons of various social status by keeping close relationship with them from childhood and how to live a fruitful life. This can be appreciated as a life objective also. The concept of Sadis $\square$ or Six Directions presents the relationship that develops gradually between person and society and also the duties that should be done by each one on various occasions.

If the society is formed with the above mentioned education objectives, there won't be any social problem, complexity or any corruption. In this manner, for the benefit of social expertise, it is possible to understand how people get help and support from Buddhist doctrine.

Buddhism accepts that it is necessary to teach a person how to live righteously and happily. For this, Buddhism says that there are four kinds of happiness. There are Atthi Sukha, Bhoga Sukha, Anana Sukha and Anavajja Sukha. Atthi Sukha means the ability to enjoy that one has property that earned hardly and righteously. Bhoga Sukha means the happiness one gets by thinking about the ownership of property. Here, it is necessary to connect donating things 


\section{Asia Pacific Journal of Advanced Business and Social Studies \\ ISBN (eBook): 9780994365675 | ISSN : 2205-6033 \\ Year: 2017, Volume: 3, Issue: 2}

to others in the same category, Bhoga Sukha. Anana Sukha is the happiness that one does not loan or borrowed money. When one earns money, if one feels that he earned money without taking on credit, it is also Anana Sukha. Anavajja Sukha means the happiness that one gains by thinking of the way of earning property in a righteous way. According to Eight Fold Path - Sa×m $\square(j \times v a$ (right livelihood), and the ideas presented in discourses like Sing $\triangle$ lov $\llbracket d a, V y a g g a p a j j a$, it is to consider that one lives with hard-earned property. In this fourfold happiness, it is necessary to live in a way that one can enjoy them and build up life according to them. And Buddhist education does this work(Nipita \& Andersen, 1997, p. 157).

An important thing that Buddhism expects is to create a person with high self-confidence. According to Buddhism, the greatest self-confident person is not to worry even facing with Eight Worldly Conditions ( $A_{\supseteq} \supseteq$ Dhaloka Dha $\propto \mathrm{ma}$ ). A person's life does not remain with happiness or sorrow. But, he has to face eight worldly conditions. From childhood when facing incidents like these, teaching them how to react is a training with the objectives of Buddhist education. Then, he does not face sadness or unrest. Person always leads an unhappy life and Buddhism presents the main reason as Craving (trusna). He dies full of desires and with the inability of achieving them. It is a suffering for him. If he is to lead a free life from it, he has to get the training for a simple and moderate(Nipita \& Andersen, 1997, p. 25).

The ways that new things should be taken into one's life is that they should not be a burden into his life. Since person is addicted to an artificial life not a real life, he does self-cheatings. It means that he exaggerates self to the external world hiding the real nature. In that process, he will be unable to distinguish his real nature and life will be a burden to him. By not putting life to such a fate, Buddhism teaches the doctrine that is helpful for a better development of life. Discourse on Loving-kindness states 'satussako, subharo, appakicco, sallahukawutti' which presents person to live a wealthy life, education, family life condition, living environment, the position of his parents and by thinking about them to live with what is available.

Foundation for self-economy and following a routine that is suitable for the social status, creating power that is necessary for nourishing life and maintaining it, the complexities that are maintained by various persons and institutions, without attachment to all of them, leading a busy and restful life, acting in a meaningful way by doing only few activities in a more successful manner, free from false social and cultural level, free from ethics that is difficult to bear and with simple lifestyle, confirming a lifestyle of good conduct is affecting for the development of person and the Buddhist objective is to make person into that state. The above mentioned factors are highly concerned in this regard.

One of the objectives of Buddhist education is to train a person to look at self and others with love and respect. Without being selfish and leading to act selflessly is done with this objective. In Buddhism, this has been presented as Attupan $\square$ ika Dhamma(Nikoya \& Feer, 1989, pp. 352-356).

Human right protection that has been a burning issue to the entire world is also paid attention to here. When human rights are concerned, person by entering the mind in an honest way, thinking that a particular thing is not suitable to self and others also decide that certain thing is not suitable for them, do not do the things that are dangerous to self and others and must try to do only the good deeds.

The main code of ethics of Buddhism, Pancasila (Five Precepts), is the principle of protecting human rights. Five Precepts are considered as five rules that are compulsory for the benefit of person. These have become very useful with a great value. The facts found in Five Precepts are abstaining from killing beings, taking things not given, sexual misconduct, telling lies and having drinks that cause intoxication and heedlessness. 


\section{Asia Pacific Journal of Advanced Business and Social Studies \\ ISBN (eBook): 9780994365675 I ISSN : 2205-6033 \\ Year: 2017, Volume: 3, Issue: 2}

If these five facts are operated within a social framework, it is not possible to continue that society. So, it is possible to accept these five as fundamental human rights. The precept on killing beings presents security of saving each other's lives socially. If someone desires for one's life, in the same manner, as the first precept certifies, others desire their lives. It has been taught that all should behave keeping this idea in mind (Dhammananda \& Pili, 1982, p. 129). From these, the first human right i.e. 'all should live freely without any hindrance' is preserved. The special feature of Buddhism is accepting that this right should be with all the beings. Buddhism does not limit it to human beings(Kolidasa, n.d., p. 347).

The second right of a member of society is the right to earn money and use them. That right is preserved from the first precept on killing beings. This precept presents rights and duties both of which are concepts in society. This says that there is right to get protection from stealing and reveals that it is a duty not to steal.

As a human being, person has the right to lead a family life by enjoying five sensual pleasures. Accepting this with honour, without disturbing that happiness, this presents that it is one's duty to let others live freely. Creating the basic foundation for the benefit of the whole society is done with the third precept on sexual misconduct.

At social and economic activities, a person's trust and honesty is very important. In this respect, fourth precept on lying affects greatly. Wrongs, done verbally like Pisun $\square v \square c \backsim$ (slander speech), Pharus $\square v \square c \square$ (harsh speech) and Sampapphal $\square$ p $\square$ (useless speech), are also in the fourth precept. If everybody in society cheats each other and live, that society won't be a good society. Then, it is a huge blow to the human right of living peacefully due to the breaking down of friendship and belief among each other. So, keeping the fourth precept is also a human rights' protection.

Not respecting the fifth precept will result in breaking the above mentioned four human rights. Through drinking liquor, one loses real consciousness and becomes lunatic. Therefore, he does not care law, religion, values etc. He does not do any good to society. He plunders the rights of other members of society. It can be stated that breaking of the fifth precept will cause many human rights violations.

As a whole, Five Precepts protect freedom and the right to live, not only of human beings, but for all beings. The objective of Buddhist education is to create the well-being or benefit of person and society. It is very clear now that five precepts are necessary to create world peace and to end the worldwide spread environment of unrest or intolerance. This is against loving-kindness(Chandima, 2003, p. 36). When Buddhist education aims and objectives are concerned, there are few important facts in the Discourse on Blessing (Mangala Sutta). 'Vast learning, perfect handicraft, a high trained discipline, and pleasant speech. This is the Highest Blessing(Nipita \& Andersen, 1997, p. 47).'

In this way, the facts like vast learning, skill in handcraft, well grounded in discipline, pleasant speech consider as the highest blessing. It is necessary to examine these one by one.

$B \measuredangle$ husacca or vast learning means gaining a vast knowledge(Jotik, 1952, p. 87). In a religious sense, learning about Nine-fold Dispensation (nav $\square$ nga sattus $\square$ sana) and the ability to describe them in various ways. The objective of Buddhist education is not only to give this energy but it is necessary to put those theories into practice. Moreover, the person who does not follow the doctrine has been compared to a shepherd(Dhammananda \& Pili, 1982, p. 19).

Sippa $\equiv$ or the skill in handicraft means gaining the knowledge of handicraft(Jotik, 1952, p. 87). According to this, it is clear that giving students some knowledge of some traditional handicrafts and other crafts has been accepted in Buddhism as an objective of education. 


\section{Asia Pacific Journal of Advanced Business and Social Studies \\ ISBN (eBook): 9780994365675 I ISSN : 2205-6033 \\ Year: 2017, Volume: 3, Issue: 2}

These crafts have been given as secular or household (ag $\sqsubset$ rika) and homeless or non-worldly (anag rika). Without becoming a hindrance to the internal life and Buddhist convention has accepted that it is good to engage in occupations connected to gold etc.

Homeless (anag $\square$ rika) crafts have been presented well as the knowing things like sewing robes(Jotik, 1952, p. 87). From this, it has been intended to train some craft related to their live to both the laity and clergy. It is clear now that Buddhism has recommended this. At Sing $\square$ lov $\square$ da Sutta, by introducing the duties towards the parents, the Buddha has preached the world that the crafts are to be learnt and it has been presented as a duty(Nikoya \& Feer, 1989, p. 189). This is not only an objective of education but also Buddhism accepts them to be a social necessity. This shows that it agrees with the modern views. If education provides jobs, the national development of country depends on education. Therefore, it is clear that education must certainly consist of economic goals and contain them(Sri Lanka University, 1980, p. 31).

When person and social development is concerned, both male and female as the partners of the society have to engage in various crafts with their abilities and Buddhism accepts it as an education concept. The Buddha has preached in Uggaha Sutta that females have to learn the crafts that can be learnt from being at their home. The female who is getting ready for marriage should learn crafts like spinning cotton, embroidering goat-hair, sewing etc. Since the word, 'Sikkhitabba” has been used, it emphasises that it is necessary to have a good discipline and training. This training can be taken into use in household activities and also in economic activities.

When it is considered like this, the modern idea "Education for Living" has been presented by the Buddha hundreds of years ago. At the same time, this is meant that the knowledge of various crafts should be given to all without considering the difference like masculine, feminine etc. So, no one can argue that the objectives of Buddhist education are directed to the non-worldly section. Buddhist Philosophy of Education is with the objective of creating complete lifestyles of the masses.

Discipline is the controlling body and speech. This is very important as an education objective. The knowledge that a person gains on crafts without any discipline is not for the good of society but the Buddhist view is that it should be with ethics. The intelligence of the person, who is without virtue and discipline, is fruitless(Tilakasiri \& Sahitya, 1958)

The harmful scientific productions that are visible in the world are all without the virtuous control and they are the results originated from intelligence. Specially, Buddhism commonly emphasises Eastern thinking philosophy. It is essential for the person not only to gain the knowledge but also to have discipline, virtue of physical and mental. The knowledge without virtue and ethics is always selfish and person is persuaded to various social oppressive deeds. The main reason for crimes that are developing in various forms in the modern world is the one-sided nature of education. It is possible to see that the modern educationalists have understood this situation. It is clear from 'one of the main activities of an education process is training members to live honouring the other members of the society(Peters, 1966, p. 52).' From the above R.S. Peters' idea, it is clear. Due to one-sided education receiving even from the early childhood, the world has become a place filled with trouble. The inter-personal troubles have become external troubles. After educating others about these troubles, Buddhist education explains how to solve them. It has been given in brief in the verse in (Nikoya \& Davids, 1991, p. 29).

From this, it teaches that in the firm foundation named virtue $(s \times l a)$ and by cultivating mind and wisdom, it is possible to solve problems due to bad mental conditions. It is not necessary to become an Arahant to get this situation. It is more than enough to understand questions 


\section{Asia Pacific Journal of Advanced Business and Social Studies \\ ISBN (eBook): 9780994365675 | ISSN : 2205-6033 \\ Year: 2017 , Volume: 3, Issue: 2}

with wisdom and with some understanding. Professor Hewage, (1970) presents several education objectives formed with the Buddhist philosophy in the following manner.

1. Giving the ability, attitudes, knowledge for a person to face life successfully,

2. Helping to build up personality and make the maximum benefit with the inborn ability

3. Providing the chance to get attitudes, abilities etc. to understand the real nature of self and surrounding environment

4. Having known the real nature of human nature, according to them, in a way that others may get happiness, the effort done to achieve this.

When discussing Buddhist education objectives and guidance for a good education is fulfilling personal and common objectives, and training for living a complete life, worldly life organization of Buddhism has been presented in brief in the following verse(Nipita \& Andersen, 1997, p. 149).

Not to do any evil, to do good, to purify one's mind, this is the advice of all the Buddhas. It is important to examine this further. $P \sqsubset p a$ means another name for demerits. Not doing demerits means not engaging in sin, demerit or bad deeds.

$A \propto b a l a \supseteq \supseteq$ hika $R \_$hulov $\square$ da Sutta teaches the theories to decide merits and demerits.

According to them, if an activity does not benefit oneself, others and both self and others, it is a demerit. It is necessary for person to avoid them and Buddhist education leads to get rid of these wrong things and teaches to do good. In the Discourse on Blessing, 'atthakusalena', the meaning given commentary, it is possible to give the meaning 'clever' for 'Kusala'. This further proves by 'attha kusalena checoti vutta $\propto$ hoti'(Jotik, 1952, p. 57). It is necessary to arrange all the activities cleverly and for the benefit of the whole society and also for the self. At the end, it is essential to arrange all the activities to purify mind. It is very clear that the initial and final objective of Buddhist education is purifying mind, "sacitta pariyo dapana $\propto$ ". The Buddhist education system has been formed in a way that it shows life objectives and education objectives.

\section{Conclusion}

In conclusion, it is obvious that Buddhism accepts the change of society and person. It has to be done with more care through the Buddhist education objectives. It is crystal clear that the initial and final objective of Buddhist education is to purify ones mind. One can achieve the deliverance as the final goal in life by following the Buddhist Philosophy of Education. Buddhist Philosophy of Education has been formed in a way that it shows life objectives and education objectives in a successful manner. Buddhist Philosophy of Education is based on the Buddhist philosophy about the society and the person. It is possible to state that the person is the central point in Buddhist Philosophy of Education. The main element of Buddhist Philosophy of Education is to encourage the person to engage in real learning through the factors like morality, concentration and wisdom. The ultimate target of Buddhist Philosophy of Education is to sacrifice for the spirit and achieve emancipation. 


\section{References}

i. Abhayawansa, K., 2004. 4oth Commemorate Volume. 40th ed. Nugegoda: Samagree Buddhist Committee.

ii. Bhasham, A., 1962. Asirimath India. Colombo: Rajyabhasha Department.

iii. Chandima, W., 2003. Nivan Maga (9 Kalaba), s.l.: Pacaslaya Ha Nutana Samajaya.

iv. Davids, R. \& Stede, 1966. Poli-English Dictionary, London: Poli Text Society.

v. Dhammananda, K. \& Pili, D., 1982. Sasana Abhiwurdhi Wardhana Society. 123 ed. Jalan Berhala, Balaysia: Sasana Abhiwurdhi Wardhana Society.

vi. Hawanapola, R. \& muladarma, A., 1974. Colombo, Colombo: s.n.

vii. Hendri, W., 1977. Adyapana Darsana Prawesaya, Colombo: s.n.

viii. Hewage, L., 1970. Budhis Education. s.l.:Buddhis Education.

ix. Jotik, P., 1952. Sirinatha Kumaradasa Moonasinghe ESQ, Colombo: Maligakanda.

x. Kandima, V., 1993. Early Buddhism - its Religious and Intellectual Milleu, Colombo: s.n.

xi. Karunaratna, 2000. Concept of Freedom and Responsibility in Theravada Buddhism in V.C.K.. 17th ed. s.l.:VCK.

xii. Kolidasa, n.d. Raghuwansa Epic. 1080 ed. Calcutta: Pandit Jibananda Vidyasagara.

xiii. Manusmmriti \& Panday, P. H., 1969. Bombay: The Gujarat Printing Press.

xiv. Narada, R., 2000. Dhammapada. Dehiwela: Buddhist Cultural Centre.

xv. Nettananda, S., 1973. Addhyapana Manovidyawa, Colombo: Addhyapana Manovidyawa.

xvi. $\quad$ Nikiya, A. \& Davids, R., 1995. 4th ed. Oxford: Pali Text Society.

xvii. Nikiya, D. \& Davids, R., 1995. 3rd ed. Oxford: Pali Text Society.

xviii. Nikoya, M. \& Davids, R., 1991. 2nd ed. Oxford: Pali Text Society.

xix. $\quad$ Nikoya, S. \& Feer, L., 1989. Colombo: Pali Text Society.

xx. Nipita, S. \& Andersen, O., 1997. Oxford: Pali Text Society.

xxi. $\quad$ Peters, R., 1966. Ethics and Education, London: s.n.

xxii. Pili, P. \& Hewawitarana, 1950. Sirinatha Kumaradasa Moonasinghe ESQ, Colombo: Maligakanda.

xxiii. Rolinson, 1959. Indian Cultural History, Colombo: Ceylon Government Press.

xxiv. Sri Lanka University, 1980. Education Diploma, Colombo: Sri Lanka University.

xxv. Tilakasiri, J. \& Sahitya, V., 1958. Colombo: s.n.

xxvi. Vilsin, S. \& Hewawitarana, 1929. Sirinatha Kumaradasa Moonasinghe ESQ, Colombo: Maligakanda.

xxvii. Whitehead, A., 1929. The Aims of Education, s.l.: s.n. 
